The Crystal Growing Technology and the Crystal Bank

\section{Se-Young JEONG}

The sample is the most important thing for physicists and material scientists studying condensed matters. Today, the leadership of the world-wide research depends on the advanced sample and most of leading researches in condensed matter are related to new material and crystal growth. We are always considering what kind of new crystal we should grow, and how we grow. The crystal bank is an institute, through which the research samples are supplied to the researchers who cannot prepare the sample by themselves. Our next goal in the near future is to provide more and new advanced crystal samples and measurement data to the researcher so that they can accelerate their research.

단결정이란 주기적으로 배열된 원자구조를 갖는 고체를 말 한다. 단결정이 아닌 물질도 주기적 원자 배열을 부분적으로 가질 수 있지만 이 주기적 배열을 갖는 영역이 무척 작다. 일 반 물질을 녹는점 이상의 온도로 가열하여 녹인 다음 자연 냉각을 할 경우 원자들은 수백 $\mathrm{nm}$ 이상의 주기적 배열을 갖 기 어렵다. 물질 내 주기적 배열을 갖는 영역을 grain이라고 하고 grain boundary는 결정 구조 내 결함으로 간주된다. 이 grain boundary는 물질의 전기전도도, 열전도도를 떨어 뜨릴 뿐만 아니라 강도에도 영향을 주고 부식을 가속시키는 등 물성에 악영향을 미친다. 결정 시료를 확보한다는 것은 물 리학자로서는 그 물질의 순수한 원천적 성질을 조사할 수 있

\section{저자약력}

정세영 교수는 1990년 독일 Koeln 대학에서 이학박사학위를 받았다. 1991 년 한국전자통신연구소 선임 연구원으로 재직하였고 1991년 후반부터 부 산대학교 물리학과에서 교수로 재직하였으며 2002년부터 현재까지 부산대 나노과학기술대학 교수로 재직하고 있다. 1998년경까지는 주로 강탄성 물 질과 정합-비정합 물질에 대한 결정성장 및 domain 구조 연구를 하였고 그 이후 자성반도체 물질에 대한 연구, 수소 매개에 의한 스핀 정렬, 스핀 양자 소자 연구 등을 진행해 오고 있으며 최근에는 수소저장체, 투명전극 물질 및 금속 단결정 등 새로운 물질 개발을 위해 노력하고 있다. (syjeong@pusan.ac.kr)
다는 것이다. 결정에 따라 투명한 결정의 경우는 탁월한 광학 적 특성을 이용하여 광학적 특성을 연구하는 데 사용될 것이 고 물질에 따라 반도체, 자성체, 금속, 초전도체 등 다양한 형 태의 단결정으로 성장될 수 있다.

\section{대표적 결정성장 방법}

\section{1. 수용액 결정성장 방법}

바닷물을 퍼 올려 가둔 염전에서 바닷물을 증발시켜 소금 을 얻는다. 이는 바닷물에 용해되어 있던 $\mathrm{NaCl}$ 성분이 물이 증발하면서 결정화가 되는 현상으로, 수용액에서의 결정성장 법(solution growth method)의 원리가 이와 같다. 즉, 수용 액 결정성장법은 성장하고자 하는 물질을 포화상태로 용매에 녹인 후 일정하게 온도를 유지하면서 용매를 증발시키거나, 온도를 서서히 떨어뜨리면서 용질이 석출되는 현상을 이용한 성장법이다. 그 과정을 간단히 포화용액의 제조, 시드의 제조, 시드의 투입, 결정성장의 네 단계로 요약할 수 있다.

포화용액을 만들 때 용매로는 증류수를 가장 많이 사용하 므로 물에 녹는 물질이면 결정으로의 성장이 가능하여 비교 적 쉽게 결정을 얻을 수 있지만, 불순물이나 진동이 들어가지 않은 상태에서 온도를 일정하게 유지하거나 온도를 서서히(약 $0.2^{\circ} \mathrm{C} /$ day) 내려야 하는 등의 어려움이 있으므로 질 좋은

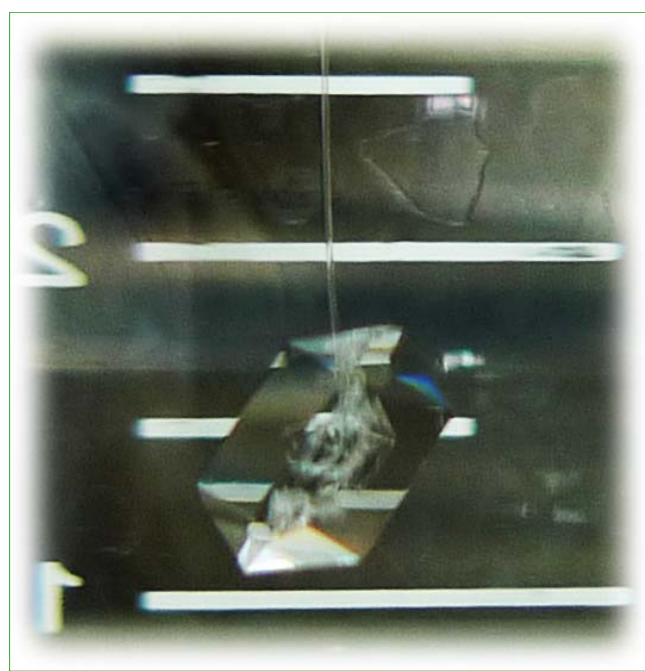

Fig. 1. Growing crystal in the solution. 


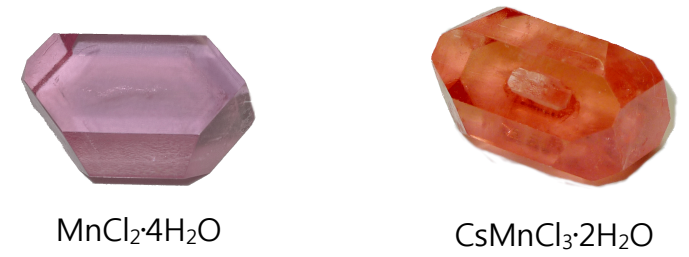

Fig. 2. Sample crystals grown by the solution method.

단결정을 얻기 위해서는 다른 결정성장 방법과 마찬가지로 노하우가 필요한 결정성장법이다.

또한, 수용액 결정성장법은 다른 결정성장방법에 비해 긴 시간이 걸리는 단점도 있지만, 시드를 포화 용액 속에 매달아 네 방향으로 자유롭게 성장시키기 때문에 성장된 결정이 고 유한 결정성을 보여주고 발달면이 뚜렷하여 결정축을 결정하 기 용이하고, 교육에 활용하기에도 용이하다. 또한 특정 불순 물을 첨가하여 성장하기도 하고, 중수를 용매로 활용하여 성 장하는 등 단결정 성장의 폭을 넓혀주어 다양한 특성을 가진 단결정을 얻는 데 많이 이용되고 있다.

이렇게 수용액 결정성장법으로 성장시킨 결정에는 $\mathrm{AH}_{2} \mathrm{PO}_{4}$ $\left(\mathrm{A}=\mathrm{K}, \mathrm{NH}_{4}, \mathrm{Cs}\right.$ 등), $\mathrm{ABCl}_{3}(\mathrm{~A}=\mathrm{Cs}, \mathrm{K}, \mathrm{Rb}, \mathrm{B}=\mathrm{Co}, \mathrm{Cu}, \mathrm{Zn}, \mathrm{Cd}$, $\mathrm{Mn}$ 등), $\mathrm{LiASO}_{4}\left(\mathrm{~A}=\mathrm{Cs}, \mathrm{K}\right.$ 등), $\mathrm{CuSO}_{4} \cdot 5 \mathrm{H}_{2} \mathrm{O}, \mathrm{K}_{3} \mathrm{Fe}(\mathrm{CN})_{6}, \mathrm{DKDP}$, $\mathrm{KDCO}_{3}, \mathrm{NiSO}_{4} \cdot 6 \mathrm{H}_{2} \mathrm{O}$, Rochelle Salt, TGS 등이 있다.

\section{2. 쵸크랄스키 결정성장법}

쵸크랄스키법(용융인상법)은 1816년 쵸크랄스키가 납 $(\mathrm{Pb})$ 의 표면장력을 측정하기 위해 고안한 장치에서 시작되었다. 금속 결정의 성장에서 약 150 년 뒤에 이르러 산화물 결정, 그리고 반도체 $\mathrm{Si}$ 단결정의 육성, 제조 가능한 기술로 개화된 기술이 다. 쵸크랄스키법의 이점은 첫째, 육성 결정이 도가니에 직접 접하지 않기 때문에 도가니에 의한 반응, 수축응력 등의 제약 이 적고 둘째, 임의 결정 방위로 단결정을 육성할 수 있으며 셋째, 대형 단결정이 재현성 있게 얻어지며 넷째, 육성 중에 상태 관측이 가능하다는 것 등이어서 금속이나 산화물 결정 을 얻는 데 최적의 방법 중 하나라 할 수 있다. 반면 쵸크랄 스키 결정성장의 약점은 사용하는 도가니의 녹는점에 따라 그 이상 온도의 녹는점을 갖는 물질은 성장이 불가하다는 것 이다. 또한 결정 전체의 균질성을 확보하기 위해서는 콩그루언 트한 방법에 의해 결정성장을 하여야 하는 부분도 이 방법에 의한 결정성장의 어려움 중의 하나이다. 쵸크랄스키법을 이용 한 결정성장 장비의 이미지를 그림 3(a)에 나타내었다. 그림 $3(\mathrm{~b})$ 는 결정이 성장되는 모습을 나타낸다. 단결정 성장 시 중 요한 요소로는 결정 인상속도와 결정 회전 속도의 두 가지가 있지만, 이것들은 독립변수가 아니고 결정성장로 내의 온도 분포와 밀접하게 연관되어 있다. 그리고 이들 세 가지 요소에

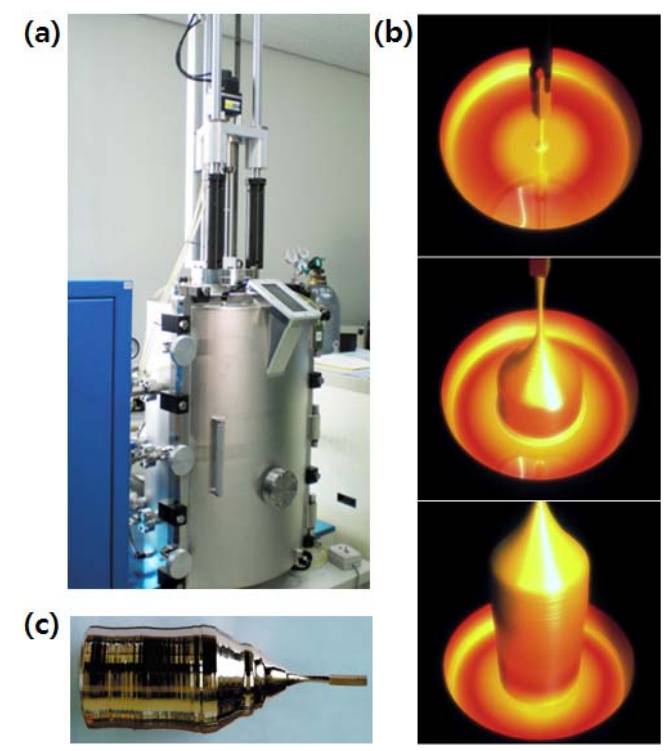

Fig. 3. (a) Czochralski crystal growth system. (b) Growing crystal from the melt. (c) Grown copper single crystal.

더하여 육성 결정의 크기, 도가니의 형상 및 지름, 도가니 내 융액의 깊이, 결정의 융점, 융액의 점성, 인상 결정의 방위, 결정 육성시의 온도 제어 등 여러 요소가 서로 복잡하게 작 용하기 때문에 단결정 육성은 전문가의 경험적 기술에 크게 의존한다. 따라서 “결정성장은 과학이 아니라 예술이다."라고 하는 이유도 여기에 있다. 그림 3(c)는 쵸크랄스키법을 이용 하여 성장시킨 구리 단결정의 모습이며 그림 4는 쵸크랄스키 법으로 성장한 실리콘 단결정과 실리콘 웨이퍼를 보여준다.

최근에는 기술이 많이 발전하여서 단결정 육성이 자동으로 이루어지게 되었다. 그러나 여전히 수동적인 방법이 많이 사 용되는 이유는 여러 가지 현상(예를 들면 고체, 액체 계면의 메니스커스 형상, 지름 변화, 성장능의 발생, 패시트 형성 등) 을 눈으로 관찰하면서 결정성장을 할 수 있기 때문이다. 새로 운 결정을 육성할 경우 가장 중요한 것은 종자 결정의 확보 이다. 보통 전혀 알려진 바가 없는 물질일 경우 새로운 종자 결정의 확보에 1 년씩 걸리는 경우도 많고 전혀 단결정 형태 로 성장할 수 없는 경우도 있다. 서양 속담에 사과는 사과나 무에서 멀리 가지 않는다는 말이 있듯이 결정성장에 있어 종자 결정은 매우 중요한 요소이다.

\section{3. 브리지만법(Bridgman method)}

브리지만법은 두 개의 온도가 다르게 조절되는 전기로를 아 래위로 설치하고 그 내부에 밀폐된 앰플 내에 성장하고자 하는 물질의 원료시약을 넣은 다음 높은 온도 영역의 전기로에서 녹 은 앰플 내부의 시약이 낮은 전기로 영역으로 이동하면서 아랫 부분에 서서히 핵형성이 되고 앰플 내 전체 시약이 결정성장 


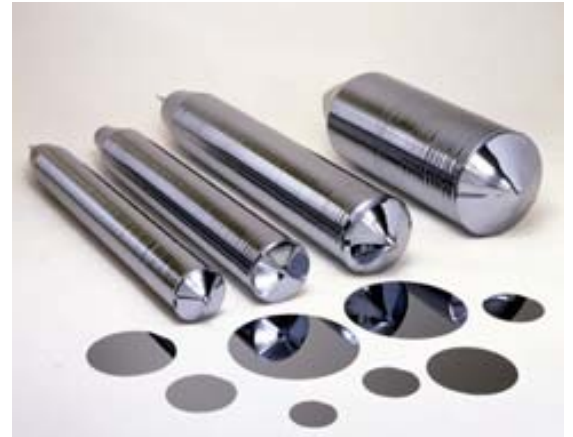

Fig. 4. Si single crystal grown by Czochralski method and wafers.

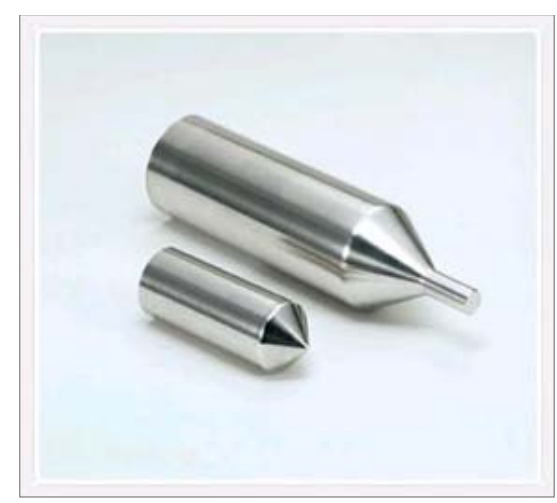

Fig. 5. Pt crucible for the Bridgman method.

되도록 유도하는 방법이다. 이 방법의 장점은 외부의 분위기와 시약을 고립시켜 반응을 막을 수 있다는 것이다. 그리고 약간 의 중발이 있는 물질이라면 앰플의 밀폐가 결정성장에 도움이 된다. 온도가 높은 전기로 부분과 낮은 전기로 부분의 온도차 는 보통 $50 \sim 100$ 도 정도되며 앰플의 모양은 튜브 형태로 유 리관이나 quartz를 사용하지만 융점이 높을 경우 백금으로 된 도가니를 사용하기도 한다. 모양은 그림 5 에서와 같이 만들어 아랫부분에서부터 결정성장이 일어날 경우 핵형성이 작은 영 역에서 일어나서 천천히 굵어지면서 성장하도록 하는 결정성 장 메카니즘을 잘 보여주고 있다. 공기 중에서 반응을 하는 물 질의 경우는 도가니의 윗부분을 녹여 밀폐하여야 하고 한번 사 용하고 나면 찟어서 성장된 결정을 꺼내고 나서 도가니는 다시 녹여 만들어야 하는 불편함과 경비의 부담이 있다.

도가니의 생긴 모양대로 결정이 성장하기 때문에 좋은 점도 있지만 종자결정을 사용하는 효과를 보기가 어렵고 결정이 자 라고 있는 장면을 볼 수가 없는 등 쵸크랄스키법보다 더 좋은 결정의 질과 더 큰 결정을 얻을 수 없다. 하지만 비교적 처음 시도하는 결정의 성장에 손쉽게 적용해 볼 수 있는 방법이다. 유사한 방법으로 스토크바거(Stockbarger)법이 있는데 두 방 법의 차이점은 브리지만법은 결정이 성장되어지는 앰플에 냉 각을 통해 온도 기울기를 주어 아랫부분부터 성장이 되도록 구현하는 방법인 반면 스토크바거법은 앰플이 온도경사가 있
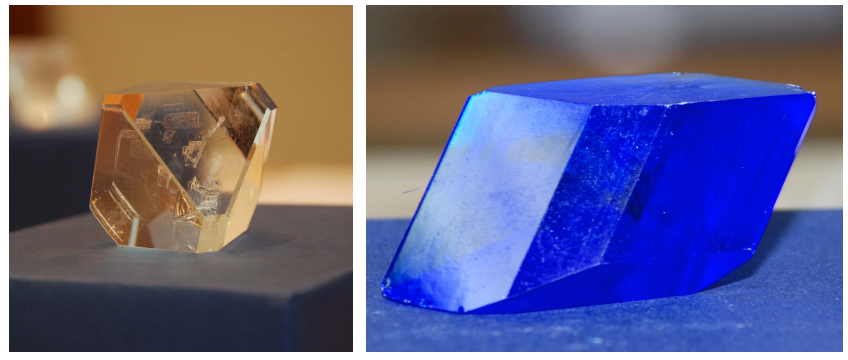

Fig. 6. KDP and $\mathrm{CuSO}_{4} \cdot 5 \mathrm{H}_{2} \mathrm{O}$ single crystals grown by junior and high school students at Korea Crystal Contest.

는 영역을 통과하며 결정이 성장되도록 인상법을 접목하였다 는 것이다. 보통 Bridgman-Stockbarger 성장법이라고 하여 둘의 장점을 접목한 방법을 많이 사용하고 있다.

\section{쉽게 성장이 가능한 물질}

쉽게 자라는 결정은 보통 핵형성 시에 결함이 많이 생기지 않으며 성장과정에서도 외부의 변수에 영향을 많이 받지 않 고 수 센티미터의 크기로 자란다. 수용액으로 결정을 성장할 경우 온도에 민감하지 않고 약간의 주변 진동에도 큰 영향을 받지 않으며 간단한 실험 장치로 성장을 할 수 있는 결정들 이 있다. $\mathrm{KDP}\left(\mathrm{KH}_{2} \mathrm{PO}_{4}\right)$, 황산구리 $\left(\mathrm{CuSO}_{4} \cdot 5 \mathrm{H}_{2} \mathrm{O}\right)$, 알룸 (백반, $\left.\mathrm{AlK}\left(\mathrm{SO}_{4}\right)_{2} \cdot 12 \mathrm{H}_{2} \mathrm{O}\right)$ 과 같은 물질은 고가의 장비 없이 간단히 스티 로폼으로 수조를 만들고 비커, 샬레, 중류수와 시약만 있으면 결 정성장이 가능하다. 단결정은행에서는 초중고생들을 위한 결정 성장대회를 15 년간 개최해 왔고 최근에 일반부도 개설이 되어서 대학생, 대학원생, 교사, 교수 등 모든 일반인들도 참여할 수 있 게 되었으므로 홈페이지(http://crystalcontest.or.kr)를 방문 하여 결정성장에 대한 정보를 얻을 수 있으며 관심이 있는 연구자는 한번 이러한 결정성장대회에 참여해 보는 것도 권 장할 만하다.

물에 녹지 않는 결정들은 고온으로 녹인 다음 서서히 결정 이 성장하도록 유도하여야 하는데 앞서 언급한 Czochralski, Bridgman법 등의 결정성장법 등을 통해서 성장이 가능한 결정들은 그나마 비교적 성장이 쉬운 편에 속한다고 할 수 있다. 반도체 기반 물질로 대표되는 $\mathrm{Si}$ 단결정은 대부분 Czochralski법에 의해 결정성장이 되고 최근에는 대기업에서 18 인치급 대형 웨이퍼 공정이 가능하게끔 설비시설을 구축한 다는 보도가 있었고 결정성장 자체는 32 인치의 크기도 가능 하다고 알려져 있다. 이러한 실리콘 단결정은 비교적 융점이 낮은 편이어서 $\left(1,414^{\circ} \mathrm{C}\right)$ 석영도가니의 사용이 가능하다는 것 이 유리한 점이다. 만약 이보다 융점이 더 높을 경우는 석영 도가니가 아니라 백금 도가니나 이리듐 도가니를 사용하여야 하는데 이럴 경우 도가니를 여러 번 반복하여 사용하는 것이 


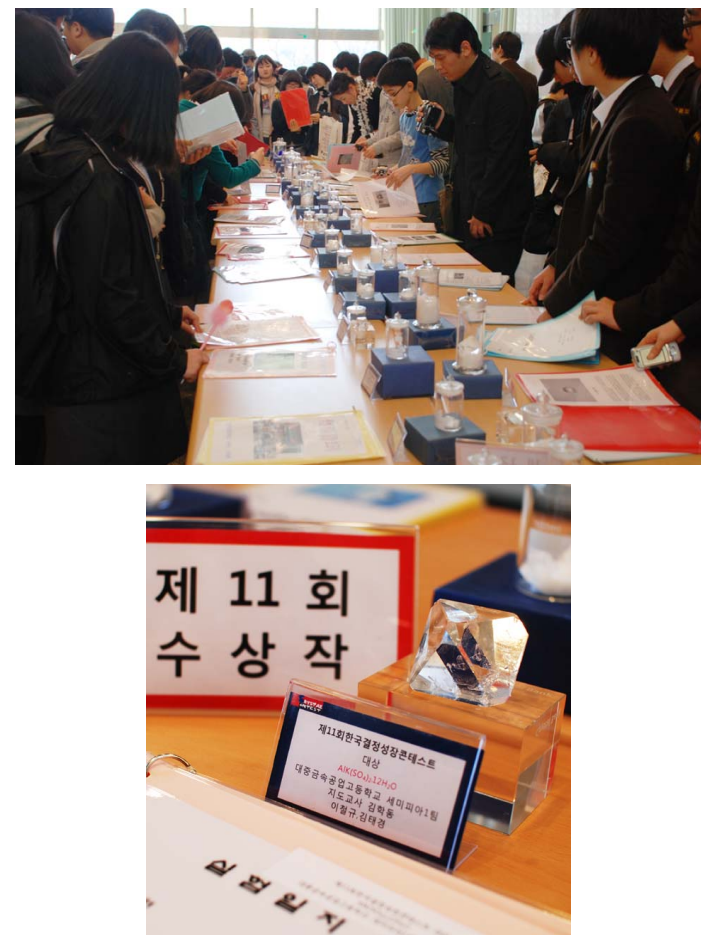

Fig. 7. Exhibition at the crystals at Korea Crystal Contest and the prize crystals.

불가능하여 수차례의 사용 후에는 도가니를 새로 교체하여야 하므로 도가니 사용에 대한 경비 부담이 커지게 된다.

단일 원소로 구성된 물질을 단결정 형태로 키우는 것은 비 교적 쉬운 편이다. 성장 속도도 시간당 $1 \mathrm{~cm}$ 정도의 성장이 가능하다. 여기에 어떤 불순물을 첨가하여 변화된 특성을 보고 자 한다면 결정성장 조건을 다시 확보하여야 한다. Seed 결 정의 확보도 중요하며 좋은 seed 결정이 없다면 seed 확보를 위해 많은 시간과 노력을 기울여야 한다. 다소 융점이 높다 하 더라도 화학적으로 안정된 물질의 경우 결정성장이 용이하다.

\section{성장이 어려운 물질: 극한 물질의 성장}

어떤 결정이라 하더라도 아주 좋은 질의 결정을 키우는 일 은 쉽지가 않다. 아주 크고 양질의 결정을 얻는다는 것은 관 련 연구자들의 꿈이다. 그러나 여기서 성장이 어렵다고 하는 물질은 일반 고온, 상압 등의 조건에서 결정성장이 불가능한 물질을 말한다. 많은 물질들이 녹는점 근처에 가면 녹는 것이 아니라 증발을 하게 되어 성장 자체가 불가능해진다. 이런 경 우 밀폐된 quartz ampoule에 넣어 증발이 되지 않도록 하여 성장을 할 수가 있다. 그러나 이마저도 녹는 온도가 낮은 경 우에 가능하고 물질의 융점이 높은 경우는 quartz를 사용할 수 없고 백금이나 기타 융점이 높은 용기를 사용하여야 한다. 백금은 융점이 높고 다른 물질과 잘 반응하지 않아 도가니
물질로는 적격이지만 워낙 고가인데다 가공 온도가 높아 실 제 사용에 제약이 많다.

$\mathrm{BaTiO}_{3}$ 와 같은 물질은 융점이 높아 바로 녹여 성장할 수 가 없어 $\mathrm{KF}$ 와 같은 융점이 낮은 flux 물질을 사용하여 그 속에서 $\mathrm{BaTiO}_{3}$ 결정이 성장되도록 하는 flux 법을 사용한다. $\mathrm{KTiOPO}_{4}$ 결정은 비선형 광학 물질로 잘 알려져 있으며 한 때 이 결정을 성장시키는 것이 어려워 관련 학계 연구자들 사이에 $\mathrm{KTiOPO}_{4}$ 단결정을 구하는 것이 대단히 중요한 문제 였던 적이 있으나 현재는 top seed solution growth(TSSG) 법을 통해 비교적 잘 성장시킬 수 있는 물질에 속한다. TSSG는 solution growth에서 수용액 내에 seed 결정을 실 로 매달아 성장시키는 것과 유사하게 녹은 flux 용액 내에 Czochralski 성장 축과 같은 결정성장 축 끝에 seed 결정 을 매달아 용액 내에서 회전시켜 성장되도록 하는 방법이다. $\mathrm{GaN}$ 와 같은 결정은 박막으로는 많이 연구가 되었으나 실제 단결정 형태로 결정을 성장한 예가 많지 않다. 알려진 결정 성장법은 고압하에서 $\mathrm{Ga}$ 과 $\mathrm{N}$ 을 화학적으로 결합하게 하는 고압성장법이 있으나 이 방법에 의해 성장된 결정의 최대 크기는 $1 \mathrm{~cm}$ 를 넘지 못해 산업적 활용은 어려운 실정이다. $\mathrm{ZnO}$ 단결정 성장에 대해서는 많은 연구자들이 관심을 가져 왔고 최근에는 몇몇 회사들에서 hydrothermal법을 사용하 여 상당한 크기의 결정으로 성장시키는 데 성공을 하였다. Hydrothermal법은 autoclave 내에 seed 결정을 매달아 두 고 물을 같이 넣어 밀폐한 후 온도를 가하면 autoclave 내 증기에 의한 고압이 형성되고 특별한 조건 하에서 결정이 자 라게 된다. 이러한 방법은 물질에 따라 조건이 잘 확보되면 한 번에 여러 결정을 성장할 수 있는 장점이 있지만 내부를 볼 수가 없고 불순물이 많이 개입되어 결정의 질이 우수하지 못하거나 성장 기간이 오래 걸린다는 단점이 있다. 최근 업계 로부터 가장 주목을 받는 단결정은 단연 사파이어 결정이다. 사파이어는 $\mathrm{Al}_{2} \mathrm{O}_{3}$ 결정을 말하며 $\mathrm{GaN}, \mathrm{ZnO}$ 박막 등 반도체 를 연구할 때 기판 물질로 많이 사용되는 결정이다. 사파이 어 결정은 앞서의 Czochralski법으로 성장이 가능하다. 그러 나 크기에 제한이 있고 성장 단가 등을 고려하여 실제 상업 화를 위한 대형 결정의 성장 방법으로는 Kyropoulos법이 주 로 많이 사용된다. Kyropoulos 법에서 $\mathrm{Al}_{2} \mathrm{O}_{3}$ 를 고온에서 녹 여 녹은 용액으로부터 결정성장을 유도하는 부분은 일반 Czochralski법과 같으나 결정성장이 이루어지는 면과 결정성 장 축의 pulling 과정이 다르다. 불순물에 민감하여 가급적 도가니를 사용하지 않고 성장을 하기를 원하거나 융점이 높 아 그 융점을 견디는 고온용 도가니가 적절하지 않을 경우 image furnace를 사용한 floating zone 방법을 사용할 수 있다.

$2,000{ }^{\circ} \mathrm{C}$ 가 넘는 물질인 경우 이 방법을 사용한 결정성장 
(a)

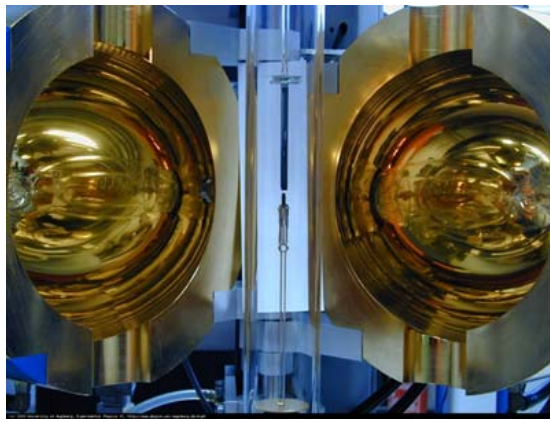

(b)

Floating-zone Pulling

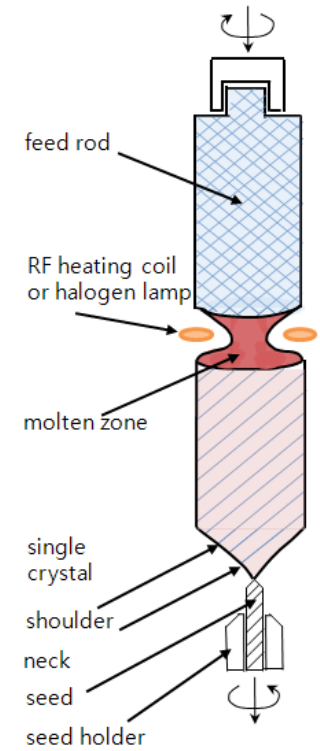

Fig. 8. (a) Crystal growth system by Floating Zone (FZ) method and (b) the detailed drawing.

법이 많이 활용된다. 분말 시료를 가압하여 성형한 막대 모 양에 할로겐 램프를 사용하여 온도를 상승시켜 일정 부분 녹 게 하고 녹은 자리를 위치 이동시키면서 결정화해나가 막대 전체가 결정화되도록 하는 방법이다. 전 세계적으로 많이 사 용되는 방법은 아니지만 성장하고자 하는 물질의 원료시약 을 공중에 띄워 두고 레이저나 고주파 방법 등으로 녹인 다 음 결정성장을 유도하는 비접촉식(containerless) 레비테이션 (levitation)을 이용한 결정성장법이 있다. 이 방법으로 개발 된 물질의 경우 도가니의 영향을 받지 않아 결함이나 구조 등에 있어서도 기존 방법으로 성장시킨 물질과 차이를 보여 물리학자들에게는 큰 관심을 받는 방법이기도 하다. 원료 물 질을 부양시켜 고온의 용융 상태를 구현하는 방법에는 정전 기적전자기적 방법, 음파를 이용하는 방법, 공기를 불어 넣는 aerodynamic법 등 여러 가지 방법이 있다. 단결정 성장이 보고된 부양기술은 정전기법과 aerodynamic법이 있는데, 가 열레이저에 의해 녹은 구형의 용융 액체를 냉각속도와 과냉 각 조절, 그리고 기체를 흘려 온도기울기를 조절함으로써, 결

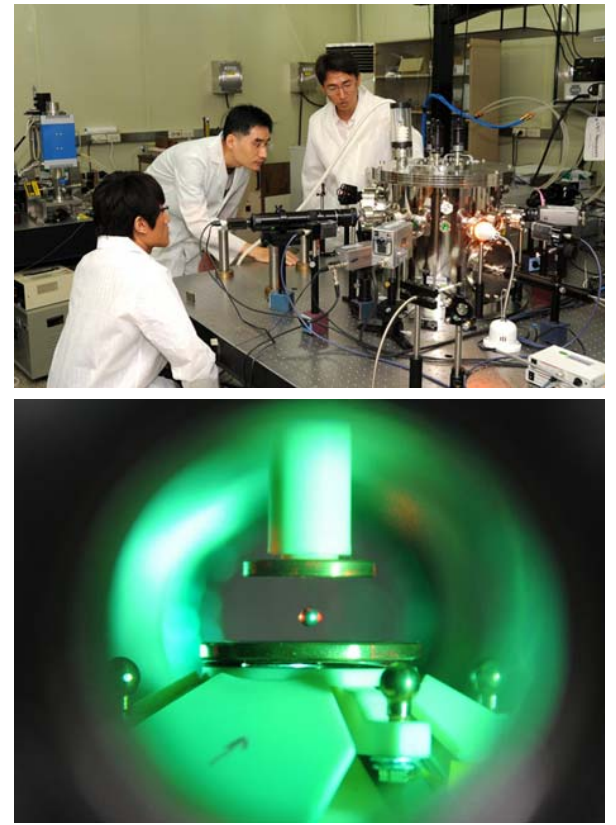

Fig. 9. Crystal growth system by the levitation method in Korea Research Institute of Standards and Science.

정성장속도와 성장 방향이 조절된다. 이 방법은 고도의 장비 설비 및 성장 기술이 필요하여 전 세계적으로 미국, 일본 등 2-3곳에서 이 방법을 사용하고 있고 국내에는 한국표준과학 연구원에 1대가 설치되어 있고 현재 2-3대의 추가 설치를 추진하고 있다.

\section{결정 소재의 활용 및 응용}

단결정 소재는 해당 물질의 순수한 특성을 조사할 수 있는 연구의 시발점이 될 뿐만 아니라, 기존의 다결정 소재로 이루 어져 온 다양한 응용 분야를 대체하여 실생활에서의 에너지, 정보 전달부터 연구에 쓰이는 고정밀의 신호 전달까지 보다 높은 양질의 결과물들을 얻을 수 있게 되었다. 실생활에 활용 되고 있는 대표적인 결정은 실리콘 단결정일 것이다. 반도체 소자의 목적을 위해 많이 활용되어 왔지만 최근에는 solar cell의 활용을 위해 많은 기업에서 실리콘 단결정 사업에 뛰어 들고 있다. Solar cell용 결정은 순도가 높지 않아도 되고 결 정성도 일반 반도체용보다 낮아도 되어 중소기업이 신사업으 로 선호하는 이유가 되기도 한다. 실리콘 다음으로 현재 응용 적 측면에서 관심을 끄는 결정은 단연 사파이어 $\left(\mathrm{Al}_{2} \mathrm{O}_{3}\right.$ 결정 $)$ 이다. 유럽과 러시아, 일본, 중국 등에서는 예전부터 이 사파 이어 단결정 개발에 많은 투자를 해 왔으나 국내에서는 1-2 개 기관에서만 부분적으로 이 기술을 유지해 왔다. 최근 LED $\mathrm{TV}$ 의 상용화에 따라 기판 물질로 사파이어 결정의 수요가 급 등하였고 특히 국내에서 이 사파이어 결정의 성장에 많은 투 
자가 이루어지고 있다. 사파이어 결정성장과 관련해서는 대형 국가 사업으로도 많이 지원되고 있으며, 최근 사파이어 관련 신설된 업체만 수십 군데이며 개별적으로 사파이어 성장 기술 을 확보하고자 하는 기관들을 포함하면 100 여 군데가 넘을 것으로 추측이 된다. 꾸준히 기술축적을 해온 바 없다가 시장 의 확대에 밀려 급히 시설과 물량을 맞추려 하다 보니 기술료 유출이 막대하다. 이번 사파이어 관련 투자 및 개발 집중 현 상은 앞으로 어떤 물질이 중요해질지 모르는 소재 산업분야에 정책적으로 꾸준히 투자해야 할 이유를 제시하고 있다.

강유전체는 외부의 전기장이 없이도 스스로 분극(자발 분 극, spontaneous polarization)을 가지는 재료로서 외부 전 기장에 의하여 분극의 방향이 바뀔 수(switching) 있는 물질 을 뜻한다. 주로 산화물이 많이 응용되고 있으며 $\mathrm{BaTiO}_{3}$ 가 가장 대표적인 재료이다. 소형 저장장치에 많이 사용되는 $\mathrm{MLCC}$ (multilayer ceramic capacitor)를 비롯하여 가스레인 지 착화기 등의 압전 응용 등 일상생활에 아주 많이 사용되 고 있다. 첨단 응용 분야로 강유전체 기억소자 $(\mathrm{FeRAM})$ 응용 을 위한 박막 연구가 지난 20 년 정도 활발히 진행되었으나 최근 에는 조금 주춤해진 상태이다. 레이저용으로는 $\mathrm{YAG}\left(\mathrm{Y}_{3} \mathrm{Al}_{5} \mathrm{O}_{12}\right)$, Nd:YVO, Nd:YAG, Nd:YLF, Ti:Sapphire, Yb:YAG, Er:YAG 등이 사용되고 있고 복굴절 활용 결정에는 $\mathrm{YVO}_{4}, \alpha-\mathrm{BBO}$ $\left(\mathrm{BaB}_{2} \mathrm{O}_{4}\right)$, Calcite(방해석, $\left.\mathrm{CaCO}_{3}\right)$ 등이, 비선형 광학용 결정으 로는 $\mathrm{BBO}, \mathrm{KTA}\left(\mathrm{KTiOPO}_{4}\right), \mathrm{KTA}\left(\mathrm{KTiOAsO}_{4}\right), \mathrm{LiLO}_{3}, \mathrm{LBO}$ $\left(\mathrm{LiB}_{3} \mathrm{O}_{5}\right)$ 등이 있다. 전기 광학용, 음향광학용, 압전용, 초전 용 응용 목적으로는 $\mathrm{LiNbO}_{3}, \mathrm{BBO}, \mathrm{KTP}, \mathrm{RTP}\left(\mathrm{RbTiOPO}_{4}\right)$, $\mathrm{LiTaO}_{3}$ 등이 주로 활용된다. 광학적 연구 목적으로 $\mathrm{MgF}_{2}, \mathrm{LiF}$, $\mathrm{BaF}_{2}$ 등도 많이 활용되는 물질이며 섬광체용(scintillation) 물질로는 Tl:CsI, Tl:NaI, $\mathrm{BaF}_{2}, \mathrm{BGO}\left(\mathrm{Bi}_{3} \mathrm{Ge}_{4} \mathrm{O}_{12}\right), \mathrm{CaF}_{2}: \mathrm{Eu}$ 등이 있으며 기판 결정으로 활용되는 물질로는 $\mathrm{MgO}$, 사파이 어, $\mathrm{SrTiO}_{3}$ 등이 있다.

연구되고 있는 물질은 무척 많지만 실제 생활에 사용되는 물질은 많지 않고 한 가지 물질이 여러 목적으로 사용되는 다양한 기능을 갖는 경우가 많다. 본 연구실에서는 최근 금속 단결정을 개발하여 전기신호전달 시의 노이즈를 최소화시키 는 데 기여한 바 있으며 음향기기와 계측기기에 활용하여 여 러 가지 특성의 향상을 확인하기도 하였다.

\section{단결정 은행의 역할}

단결정은행은 단결정 소재를 필요로 하는 연구자들에게 시 료를 공급하는 것을 목적으로 하는 연구소재은행이다. 단결정 은행은 1998년 설립되어 처음에는 일부 유전체 단결정 소재 를 지원하는 것에서 시작하였으나 현재는 반도체, 자성체, 금
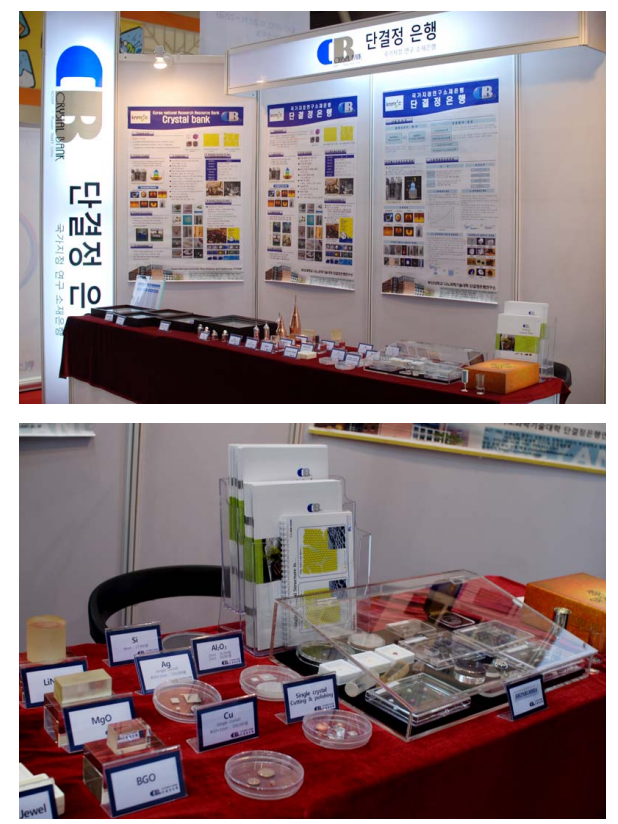

Fig. 10. Exhibition of the crystal bank at KPS meeting.

속, 박막, 분말 시료 분야까지 일부 확대하여 다양한 결정 및 시료들을 지원해 오고 있다. 현재 단결정은행이 보유하고 있 는 소재는 약 150 여 종 3,500 여 개 정도이며 매년 2,000 3,000 여 개의 시료를 대학, 연구소 및 타 기관에 공급하고 있다. 단결정은행에서 성장이 가능한 결정들은 직접 성장을 하지만 그렇지 못한 경우에도 타 기관으로부터 기탁을 받거 나 구입을 하여 가능한 한 많은 시료를 확보하고자 노력하고 있으며 연구자들이 가급적 한 번에 다양한 시료를 단결정은 행에서 확보할 수 있도록 지원하고 있다. 뿐만 아니라 기초적 인 $\mathrm{XRD}$ 측정이나 성분 분석을 위한 $\mathrm{GDS}, \mathrm{XPS}, \mathrm{AES}$, SIMS 등의 측정도 대행해 주고 있으므로 단결정은행을 잘 활용하면 연구를 위한 시간을 많이 절약할 수 있고 결정에 대한 다양한 정보와 결정학적 지식에 대해서도 자문을 받을 수 있다. 한 가지 아쉬운 점은 단결정 은행의 재료비 예산이 넉넉지 않아 많은 연구자들이 요청하는 결정 시료들을 모두 공급하지는 못하고 있다는 점이다. 향후 좀 더 큰 규모의 과 제나 국가적 지원을 통해 많은 사람들이 단결정은행의 지원 을 받을 수 있도록 하는 것이 우리의 바람이다.

단결정은행은 한국연구재단의 연구소재지원 사업의 하나이 며 물리분야에서 유일한 소재은행이다. 연구소재지원 사업은 1994년 처음 실시되어 현재 36개의 은행으로 확대 지원하고 있으나 나머지 대부분의 은행들은 생명과학관련 소재은행이다. 물리분야에서도 이러한 소재은행 사업을 희망하는 연구자들이 다수 있으나 현재까지는 여건이 제대로 마련되고 있지 않는 부 분이 매우 안타깝다. 단결정은행의 website는 http://www. crystalbank.com이며 모든 물리인들에게 열려있다. 